Pak. j. sci. ind. res. Ser. B: biol. sci. 201457 (3) 140-147

\title{
Soil Borne Fungi Associated with Different Vegetable Crops in Sindh, Pakistan
}

\section{Farzana Usman ${ }^{a}$, Muhammad Abid ${ }^{a}$, Faisal Hussain ${ }^{\text {**, Shaheena Arshad Khan }}{ }^{a}$ and Jawaria Sultana ${ }^{a}$}

${ }^{a}$ Dr. A.G. Lab. of Aerobiology and Plant Pathology, Department of Botany, Federal Urdu University of Art, Science \& Technology, Gulshan-e-Iqbal Campus, Karachi, Pakistan

${ }^{b}$ Department of Agriculture \& Agribusiness Management, University of Karachi, Karachi-75270, Pakistan

(received March 5, 2014; revised July 3, 2014; accepted July 10, 2014)

\begin{abstract}
Different soil-borne fungi are responsible for reducing the yield of vegetables throughout the world including Pakistan. There are several soil borne fungal pathogens which aggressively infect vegetable crops. Surveys conducted during September 2010 to October 2011, demonstrated that a great diversity of soil borne plant pathogens associated with different vegetables prevail in vegetable growing areas of Sindh such as Tando Allahayar, Mirpurkhas, Ghotaki, Khairpur, Kunri, Umerkot and Karachi, etc. Our study noted in total thirteen different genera of fungi isolated from vegetable crops (cabbage, brinjal, tomato, radish and spinach). Isolated fungi identified included Alternaria solani, Aspergillus flavus, A. fumigatus, A. niger, A. oryzae, A. terrus, Aeromonium fusidiocles, Cladosporium sp., Drechselra hawaiiensis, Eurotium berbanbrum, Fusarium oxysporum, Macrophomina phaseolina, Penicillium commune, Rhizoctonia solani, Trichoderma harzianum, Ulocladium sp., and unidentified black mycelium from the soil and roots of vegetable crops. In addition, it was found that soil is commonly infected by soil-borne fungi and eventually results in heavy losses of vegetable yield in the vegetable growing areas of Sindh province. The infection rapidly increased due to many factors such as, presence of moisture, cxcess of water and infection may be caused by winds, gales and dust storms as well as by mechanical vectors.
\end{abstract}

Keyword: vegetables, root-rot, soil borne

\section{Introduction}

Vegetables included in daily schedule of diet viz. sweet pepper, cauliflower, carrot, cabbage, lettuce, spinach, tomato, potato, reddish, and bottle gourd are rich in proximate composition, vitamin and mineral contents. The soil and climatic conditions of Pakistan are congenial for the production of vegetables and widely diversified agro climatic zones (Hanif et al., 2006). The nature has endowed Pakistan with diverse types of climatic conditions and land for vegetable crops. Therefore, a large variety of vegetables are cultivated in Pakistan throughout the year. In excess of 63 vegetable species are grown in various parts of the country as summer and winter vegetables particularly in Sindh province, Pakistan (Athar and Bokhari, 2006). In Sindh, Mirpurkhas division is positioned atop a fertile land making conditions suitable for cropping and vegetation. The major crops and vegetables are widely cultivated in this region (Hussain et al., 2012). Vegetables are

\footnotetext{
*Author for correspondence; E-mail: faisal.botanist2011@gmail.com
}

divided into two groups on the basis of season including winter vegetable (cultivated during the winter months of October-March) and summer vegetables (cultivated during the month of April-September). Some vegetables plants have no particular time for sowing including cucumber, radish etc. (Ali, 2000).

Vegetables are important food and highly beneficial ingredients which can be successfully utilised to build up and repair the body. They are valued mainly for their high carbohydrate, vitamin and mineral contents (Hanif et al., 2006). The yield of vegetables is reducing gradually every year due to the soil-borne fungi. It is facing several biotic problems and is under threat due to soil borne pathogens in all over vegetable growing areas. Soil-borne plant diseases cause significant damage to almost all crops particularly to the vegetables (Usman et al., 2013).

Infection of the vegetable plants in the field may occur at any time during the growing season. Early infections caused seedling blight and later infections caused foliar blight, stem lesion, vine rot, fruit rot and root and crown 
rot (Usman et al., 2013). Islam and Babadoost (2002) and Lee et al. (2001) reported that in the vegetable crops of different areas of Sindh province including Karachi (Malir, Sharafi Goth, Memon Goth and Gadap Town), Kunri, Mirpurkhas, Ghotaki, Tando Allahyar and Digri show heavy losses and several symptoms including wilting stunted growth, chlorosis, and blotch on vegetable crops. Fatima et al., (2009) indicated that Alternaria alternata, A. citri, Aspergillus niger, A. flavus, Aspergillus sp., Cladosporium cladosporioides, Drechslera australeinsis, Fusarium solani, Fusarium sp., Geotrichum candidum, Penicillium sp., Phytophthora capsici and Rhizopus stolonifer are responsible for postharvest deterioration of fresh fruits and vegetables.

The yield of vegetables is reducing gradually every year due to the soil-borne and root rot pathogens. Soil borne and root rot pathogens cause significant damage to almost all crops particularly to the vegetables. The association of root-knot with soil borne and root rot such as Macrophomina phaseolina, Fuasrium sp., and Rhizoctonia solani is causing diseases in different vegetable crops particularly chilli, brinjal, okra, tomato and spinach (Farzana et al., 2013; Hussain et al., 2013c; Maqbool et al., 1988). The soil borne root infecting fungi like Macrophomina phaseolina is reported to produce charcoal rot, damping off, root rot, stem rot, pod rot in more than 500 plant species (Sheikh and Ghaffar, 1992; Sinclair, 1982) with more than 67 hosts recorded from Pakistan alone (Mirza and Qureshi, 1978). Soil borne plant pathogens cause significant crop losses in chilli crop alone in Sindh. Root rot fungi including Fusarium sp., Macrophomina phaseolina, $R$. solani, Phytophthora root rot and Alternaria spp., are causing heavy losses in chilli and other crops (Hussain et al., 2013a; 2013b; Hussain and Abid, 2011).

The objectives of the present study were; 1) to survey the various fungi infecting (soil borne and root) vegetables, 2) to compare the fungal composition of assemblages in soil borne and root rot of vegetables in seven different localities of Sindh province, and 3) to measure the infection $\%$ of the fungal assemblages.

\section{Materials and Methods}

Collection and isolation of fungi. The root rot fungi of vegetables including cabbage (Brassica oleracea L.), brinjal (Solanum melongena L.), tomato (Lycopersicon esculentum Mill.), radish (Raphanus sativus L.) and spinach (Spinacia olerace $\mathrm{L}$.) showing wilting, stunted growth, chlorosis and blotches were collected from Sindh province including
Karachi, Tando Allahayar, Mirpurkhas, Ghotaki, Khairpur, Kunri and Umerkot from September 2010 to October 2011. The infected root samples were cut into small pieces up to 1.5 to $2 \mathrm{~cm}$ and surfaces were sterilised by $1 \% \mathrm{Ca}(\mathrm{OCl})_{2}$ for $1 \mathrm{~min}$ and these pieces were transferred on potato dextrose agar (PDA) medium and Czapek's agar medium containing antibiotic (Penicillin and Streptomycin) drops. The petri dishes were incubated for 3-6 days at $28^{\circ} \mathrm{C}$. Infection $\%$ was calculated with the help of following formula:

Infection $\%=\frac{\text { Number of plants infected by a pathogen }}{\text { Total number of plants }} \times 100$

Method of soil sampling. A total of 55 soil samples were collected between September 2010 and October 2011, from different locations of Sindh including Karachi, Tando Allahayar, Mirpurkhas, Ghotaki, Khairpur, Kunri and Umerkot. All samples were collected randomly from locations and they were associated with different vegetable fields particularly cabbage, brinjal, tomato, radish and spinach. About $300 \mathrm{~g}$ of soil was collected in polythene bags, tagged with name of vegetable and location, for each sample and taken to the laboratory for further analysis.

Soil dilution technique. One gram of soil was suspended in $9 \mathrm{~mL}$ of sterilised distilled water with the dilution of $1: 10$, followed by the dilutions of $1: 100,1: 1000$ and 1:10000. One $\mathrm{mL}$ aliquot sample was poured in sterilised petri plates containing potato dextrose agar (PDA) medium. Three replicates per sample were placed. The dishes were incubated at $30{ }^{\circ} \mathrm{C}$. The colonies of fungi on plates were counted and identified with the help of Singh et al. (1991). The number of colonies of each fungus was multiplied by the dilution factor which shows total number of propagules/g of soil (Waksman and Fred, 1922).

Identification of fungi. Isolated fungi were examined by using $10 \times$ and $40 \times$ magnifications on the microscope to identify hyphae, sporangia, sporangiophores, conidia, conidiophores and some other morphological characters including growth pattern, colony texture and growth rate of the colonies on PDA (Promputtha et al., 2005). Standard manuals or refernces including (Singh, 1991; Nelson et al., 1983; Domsch et al., 1980; Sutton, 1980; Ellis, 1976; 1971; Barnett and Hunter, 1972) were also used for the confirmation of various species.

\section{Results and Discussion}

Fungi isolated from roots. Twelve fungi were isolated from infected samples of soil collected from different vegetable crops (Table 1). Ten different fungi were 
Table 1. Fungi isolated from infected soil and roots of different vegetables collected from different areas of Sindh province, Pakistan

\begin{tabular}{|c|c|c|c|}
\hline \multicolumn{2}{|c|}{ Host } & \multicolumn{2}{|c|}{ Name of fungi } \\
\hline $\begin{array}{l}\text { Scientific } \\
\text { name }\end{array}$ & $\begin{array}{l}\text { Common } \\
\text { name }\end{array}$ & Root & Soil \\
\hline $\begin{array}{l}\text { Brassica } \\
\text { oleracea L. }\end{array}$ & Cabbage & $\begin{array}{l}\text { Aspergillus oryzae, } \\
\text { Aeromonium } \\
\text { fusidiocles, } \\
\text { Alternaria solani*, } \\
\text { Cladosporium sp., } \\
\text { Eurotium } \\
\text { berbanbrum, } \\
\text { Fusarium } \\
\text { oxysporum*, } \\
\text { Macrophomina } \\
\text { phaseolina*, } \\
\text { Rhizoctonia } \\
\text { solani*, } \\
\text { Ulocladium } \mathrm{sp} .\end{array}$ & $\begin{array}{l}\text { Aspergillus } \\
\text { flavus*, } \\
\text { A. fumigatus, } \\
\text { A. niger*, } \\
\text { Fusarium } \\
\text { oxysporum*, } \\
\text { Macrophomina } \\
\text { phaseolina*, } \\
\text { Penicillium } \\
\text { commune*, }^{*} \\
\text { Rhizoctonia } \\
\text { solani* }\end{array}$ \\
\hline $\begin{array}{l}\text { Solanum } \\
\text { melongena L. }\end{array}$ & Brinjal & $\begin{array}{l}\text { Alternaria } \\
\text { solani*, } \\
\text { Fusarium } \\
\text { oxysporum*, } \\
\text { Macrophomina } \\
\text { phaseolina*, } \\
\text { Rhizoctonia } \\
\text { solani*, } \\
\text { Penicillium } \\
\text { commune*, }_{\text {Trichoderma }} \\
\text { harzianum* }\end{array}$ & $\begin{array}{l}\text { Aspergillus } \\
\text { flavus }^{*} \text {, A. niger*, } \\
\text { A. terrus, } \\
\text { Fusarium } \\
\text { oxysporum*, } \\
\text { Macrophomina } \\
\text { phaseolina*, } \\
\text { Penicillium } \\
\text { commune*, }^{*} \\
\text { Rhizoctonia } \\
\text { solani*, } \\
\text { Trichoderma } \\
\text { harzianum* }^{*}\end{array}$ \\
\hline $\begin{array}{l}\text { Lycopersicon } \\
\text { esculentum } \\
\text { Mill. }\end{array}$ & Tomato & $\begin{array}{l}\text { Fusarium } \\
\text { oxysporum*, } \\
\text { Macrophomina } \\
\text { phaseolina*, } \\
\text { Rhizoctonia } \\
\text { solani* }\end{array}$ & $\begin{array}{l}\text { Alternaria solani*, } \\
\text { Aspergillus flavus*, } \\
\text { A. niger*, } \\
\text { Drechselra } \\
\text { hawaiiensis, } \\
\text { Fusarium } \\
\text { oxysporum*, } \\
\text { Macrophomina } \\
\text { phaseolina*, } \\
\text { Rhizoctonia solani* }\end{array}$ \\
\hline $\begin{array}{l}\text { Raphanus } \\
\text { sativus L. }\end{array}$ & Radish & $\begin{array}{l}\text { Fusarium } \\
\text { oxysporum*, }^{*} \\
\text { Penicillium } \\
\text { commune*, }^{*} \\
\text { Rhizoctonia } \\
\text { solani* }\end{array}$ & $\begin{array}{l}\text { Aspergillus niger*, } \\
\text { Fusarium } \\
\text { oxysporum*, } \\
\text { Macrophomina } \\
\text { phaseolina*, } \\
\text { Rhizoctonia solani* }\end{array}$ \\
\hline $\begin{array}{l}\text { Spinacia } \\
\text { oleracea } \mathrm{L} .\end{array}$ & Spinach & $\begin{array}{l}\text { Fusarium } \\
\text { oxysporum*, } \\
\text { Macrophomina } \\
\text { Rhizoctonia } \\
\text { solani* } \\
\text { phaseolina*, }\end{array}$ & $\begin{array}{l}\text { Aspergillus flavus*, } \\
\text { A. fumigates, } \\
\text { Drechselra } \\
\text { hawaiiensis, } \\
\text { Fusarium } \\
\text { oxysporum*, } \\
\text { Macrophomina } \\
\text { phaseolina* }\end{array}$ \\
\hline
\end{tabular}

$=*$ major fungal disease. isolated from roots of cabbage crop. Among these: Fusarium oxysporum, Macrophomina phaseolina and Alternaria solani were predominant with mean values of 65,53 and $40.57 \%$, respectively as compared to other species including Rhizoctonia solani, Aspergillus orzae, Ulocladium sp., Aeromonium fusidiocles, Cladosporium sp., and Eurotium berbanbrum. The occurrence of these three fungi was maximum in samples collected from Tando Allahyar (75\%), Khairpur (71\%) and Ghotaki (68\%), respectively, and minimum (6\%) from Mirpurkhas region. These fungi were maximum in samples collected from Kunri (67 and 65\%), Tando Allahyar and Khairpur (66\%), respectively, and minimum (7\%) from Mirpurkhas (Table 2).

The combined infection result of tomato, radish and spinach roots (Fig. 1) showed that Fusarium oxysporum was predominant with mean value of $58 \%$ as compared to other species Penicillium commune, Rhizoctonia solani and Macrophomina phaseolina. On the basis of regions, comparison the occurrence of these fungi was maxi-mum in the samples from Kunri (69 and 63\%), Tando Allahyar (67\%) and Karachi (63\%), respectively, and minimum (17\%) from Khairpur region (Table 2).

Table 3 shows the results of ANOVA for the fungal infection $\%$ on roots samples collected from various

Table 2. Infection $\%$ of different fungi isolated from roots of vegetable at various localities of Sindh province, Pakistan

\begin{tabular}{|c|c|c|c|c|c|}
\hline \multirow[t]{2}{*}{ Isolated fungi } & \multicolumn{5}{|c|}{ Root diseases infection $\%$} \\
\hline & Cabbage & Brinjal & Tomato & Radish & Spinach \\
\hline $\begin{array}{l}\text { Aeromonium } \\
\text { fusidiocles }\end{array}$ & 16.29 & 0 & 0 & 0 & 0 \\
\hline $\begin{array}{l}\text { Alternaria } \\
\text { solani }\end{array}$ & 40.57 & 41.86 & 52.29 & 0 & 0 \\
\hline $\begin{array}{l}\text { Aspergillus } \\
\text { oryzae }\end{array}$ & 32.70 & 0 & 0 & 0 & 0 \\
\hline Cladosporium sp. & 15 & 0 & 0 & 0 & 0 \\
\hline $\begin{array}{l}\text { Eurotium } \\
\text { berbanbrum }\end{array}$ & 12.43 & 0 & 0 & 0 & 0 \\
\hline $\begin{array}{l}\text { Fusarium } \\
\text { oxysporum }\end{array}$ & 65 & 60.71 & 58 & 58 & 53.14 \\
\hline $\begin{array}{l}\text { Macrophomina } \\
\text { phaseolina }\end{array}$ & 53 & 52.29 & 53.71 & 0 & 54.14 \\
\hline $\begin{array}{l}\text { Penicillium } \\
\text { commune }\end{array}$ & 0 & 27.57 & 0 & 28.29 & 0 \\
\hline $\begin{array}{l}\text { Rhizoctonia } \\
\text { solani }\end{array}$ & 40 & 39.57 & 45.14 & 45.86 & 42.29 \\
\hline $\begin{array}{l}\text { Trichoderma } \\
\text { harzianum }\end{array}$ & 0 & 15.29 & 0 & 0 & 0 \\
\hline Ulocladium sp. & 22.43 & 0 & 0 & 0 & 0 \\
\hline $\begin{array}{l}\text { Unidentified } \\
\text { black mycelium }\end{array}$ & 12.86 & 10.86 & 0 & 0 & 0 \\
\hline
\end{tabular}


localities of Sindh. Twelve fungal species including Alternaria solani, Aspergillus oryzae, Aeromonium fusidiocles, Cladosporium sp., Eurotium berbanbrum, Fusarium oxysporum, Macrophomina phaseolina, Penicillium commune, Rhizoctonia solani, Trichoderma harzianum, Ulocladium sp., and unidentified black mycelium showed highly significant differences among localities.

The infection result of brinjal roots showed that Fusarium oxysporum, Macrophomina phaseolina and Alternaria solani were predominant with mean values of 60.71 , 52.29 and $41.86 \%$, respectively, as compared to other species including Trichoderma harzianum, Penicillium commune and Rhizoctonia solani (Fig. 2).

Table 3. F-ratios derived from ANOVA for fungal infection $\%$ of roots

\begin{tabular}{|c|c|c|c|}
\hline Fungi species & F-ratio & P-value & $\mathrm{LSD}_{0.05}$ \\
\hline & \multicolumn{3}{|c|}{ Cabbage } \\
\hline Aspergillus oryzae & 206.35 & $0.0000 * * *$ & 3.71 \\
\hline Aeromonium fusidiocles & 70.11 & $0.0000 * * *$ & 2.92 \\
\hline Alternaria solani & 72.67 & $0.0000 * * *$ & 3.81 \\
\hline Cladosporium sp. & 98.84 & $0.0000 * * *$ & 2.63 \\
\hline Eurotium berbanbrum & 28.03 & $0.0000 * * *$ & 2.24 \\
\hline Fusarium oxysporum & 28 & $0.0000 * * *$ & 3.54 \\
\hline Macrophomina phaseolina & 19.14 & $0.0000 * * *$ & 3.67 \\
\hline Rhizoctonia solani & 76.16 & $0.0000 * * *$ & 3.65 \\
\hline Ulocladium sp. & 46.02 & $0.0000 * * *$ & 2.65 \\
\hline \multirow[t]{2}{*}{ Unidentified black mycelium } & 26.43 & $0.0000 * * *$ & 2.35 \\
\hline & \multicolumn{3}{|l|}{ Brinjal } \\
\hline Alternaria solani & 76.33 & $0.0000 * * *$ & 4.07 \\
\hline Fusarium oxysporum & 12.48 & $0.0000 * * *$ & 3.47 \\
\hline Macrophomina phaseolina & 74.75 & $0.0000 * * *$ & 3.05 \\
\hline Rhizoctonia solani & 83.78 & $0.0000 * * *$ & 3.45 \\
\hline Penicillium commune & 48.03 & $0.0000 * * *$ & 3.7 \\
\hline Trichoderma harzianum & 27.29 & $0.0000 * * *$ & 2.37 \\
\hline \multirow[t]{2}{*}{ Unidentified black mycelium } & 12.86 & $0.0000 * * *$ & 2.15 \\
\hline & \multicolumn{3}{|c|}{ Tomato } \\
\hline Fusarium oxysporum & 13.70 & $0.0000 * * *$ & 3.20 \\
\hline Macrophomina phaseolina & 32.37 & $0.0000 * * *$ & 4.06 \\
\hline \multirow[t]{2}{*}{ Rhizoctonia solani } & 55.46 & $0.0000 * * *$ & 4.12 \\
\hline & \multicolumn{3}{|l|}{ Radish } \\
\hline Fusarium oxysporum & 39.92 & $0.0000 * * *$ & 3.77 \\
\hline Penicillium commune & 13.28 & $0.0000 * * *$ & 4.68 \\
\hline \multirow[t]{2}{*}{ Rhizoctonia solani } & 23.86 & $0.0000 * * *$ & 3.71 \\
\hline & \multicolumn{3}{|l|}{ Spinach } \\
\hline Fusarium oxysporum & 44.5 & $0.0000 * * *$ & 3.48 \\
\hline Macrophomina phaseolina & 29.42 & $0.0000 * * *$ & 3.63 \\
\hline Rhizoctonia solani & 54.57 & $0.0000 * * *$ & 3.34 \\
\hline
\end{tabular}

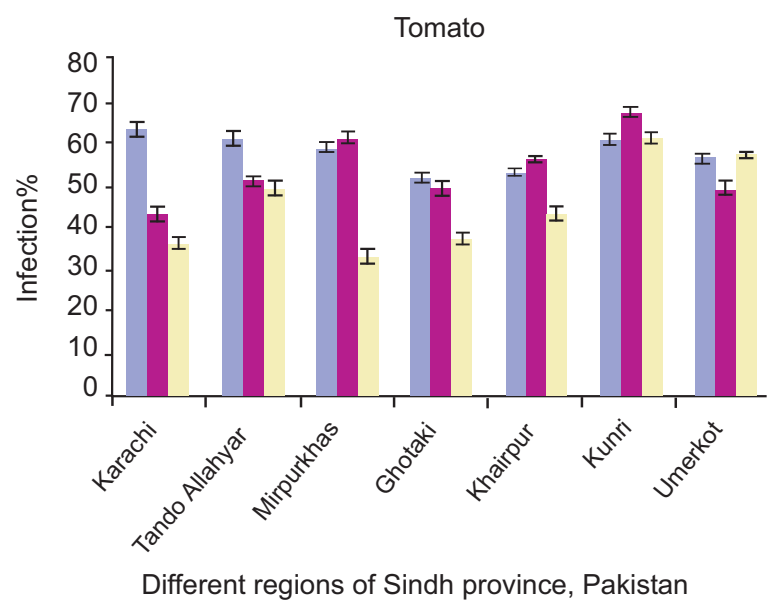

$\square$ Fusarium oxysporum $\square$ Macrophomina phaseolina $\square$ Rhizoctonia solani

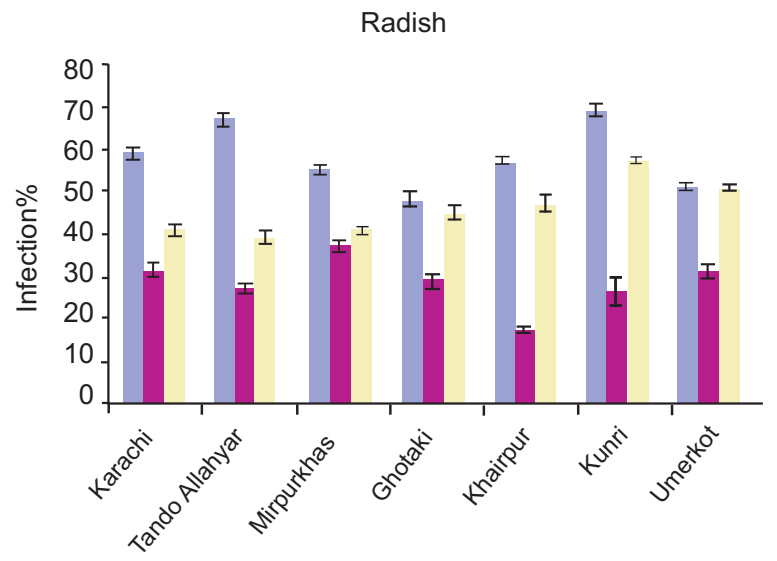

Different regions of Sindh province, Pakistan

$\square$ Fusarium oxysporum $\square$ Macrophomina phaseolina $\square$ Rhizoctonia solani

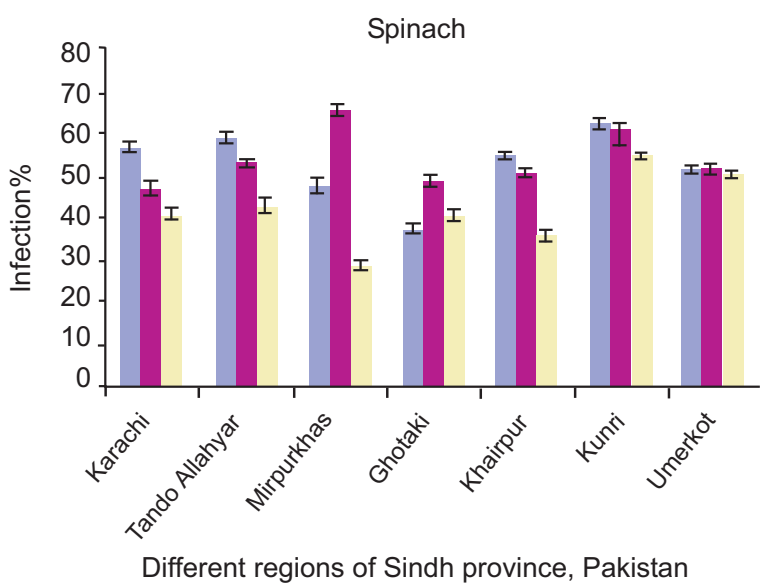

$\square$ Fusarium oxysporum $\square$ Macrophomina phaseolina $\square$ Rhizoctonia solani

Fig. 1. Infection $\%$ of different fungi isolated from the roots of tomato, radish and spinach. 


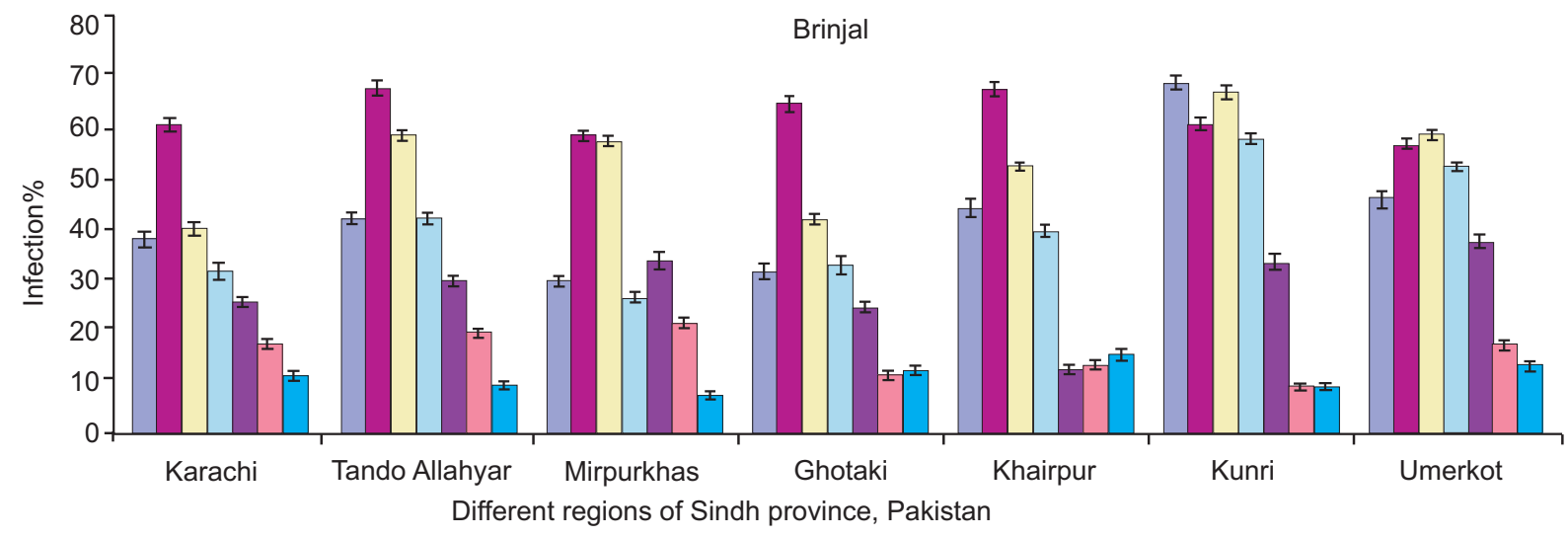

$\square$ Altemaria solani $\square$ Fusarium oxysporum $\square$ Macrophomina phaseoline $\quad \square$ Rhizoctonia solani $\square$ Penicillium commune $\square$ Trichoderma harzianum $\quad \square$ Unidentified black mycelium

Fig. 2. Infection $\%$ of different fungi isolated from the roots of Brinjal.

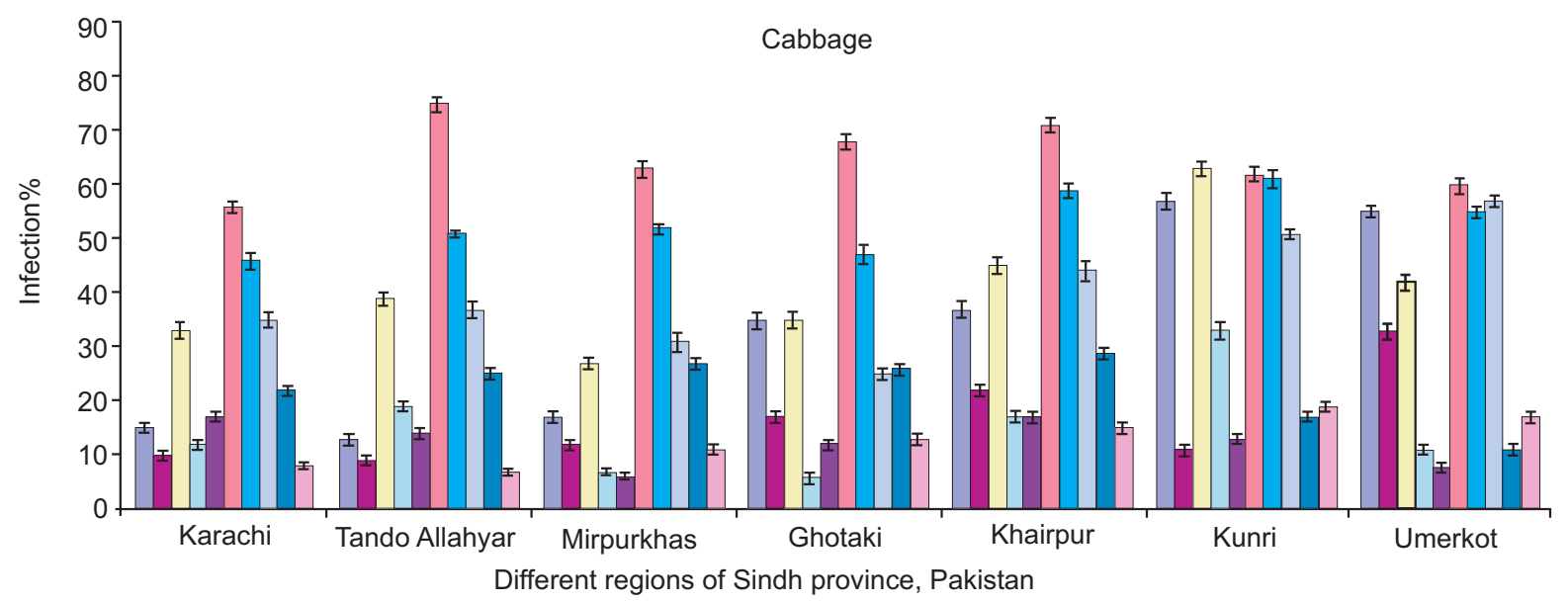

$\square$ Aspergillus oryzae $\square$ Aeromonium fusidiocles $\square$ Altemaria solani $\square$ Cladosporium sp. $\square$ Eurotium berbanbrum

$\square$ Fusarium oxysporum $\square$ Macrophomina phaseolina $\square$ Rhizoctonia solani $\square$ Ulocladium sp. $\square$ Unidentified black mycelium

Fig. 3. Infection $\%$ of different fungi isolated from the roots of Cabbage.

All twelve species are pathogenic on all vegetable particularly tomato, radish, spinach brinjal and cabbage, crops. (Fig. 1-3).

Fungi isolated from soil.Twelve fungi were isolated from infected samples of soil collected from different vegetable crops. There are seven different fungi isolated from roots of cabbage crop. Among these Aspergillus flavus, Fusarium oxysporum and Aspergillus niger were predominant with mean values of $58,56.29$ and $38.43 \%$, respectively, as compared to other species such as Penicillium commune, Aspergillus fumigatus, Macrophomina phaseolina and Rhizoctonia solani. The occurrence of these three fungi was maximum in samples collected from Umerkot
(72 and 71\%), Kunri (67\%) and Mirpurkhas (66\%), respectively, and minimum (11\%) from Ghotaki region. The infection result of brinjal roots showed that Aspergillus flavus, A. niger and Fusarium oxysporum were predominant with mean values of $51.29,39$ and $37 \%$, respectively, as compared to other species including Aspergillus terrus, Penicillium commune, Trichoderma harzianum, Rhizoctonia solani and Macrophomina phaseolina. These fungi were found maximum in samples collected from Kunri (61\%), Umerkot (57\%) and Karachi (56\%), respec-tively, and minimum (10\%) from Khairpur (Table 4).

The combined infection result of tomato, radish and spinach roots showed that Fusarium oxysporum and Macrophomina phaseolina were predominant with 
Table 4. Mean and Standard error of different fungi isolated from soil of vegetable at various localities of Sindh province, Pakistan

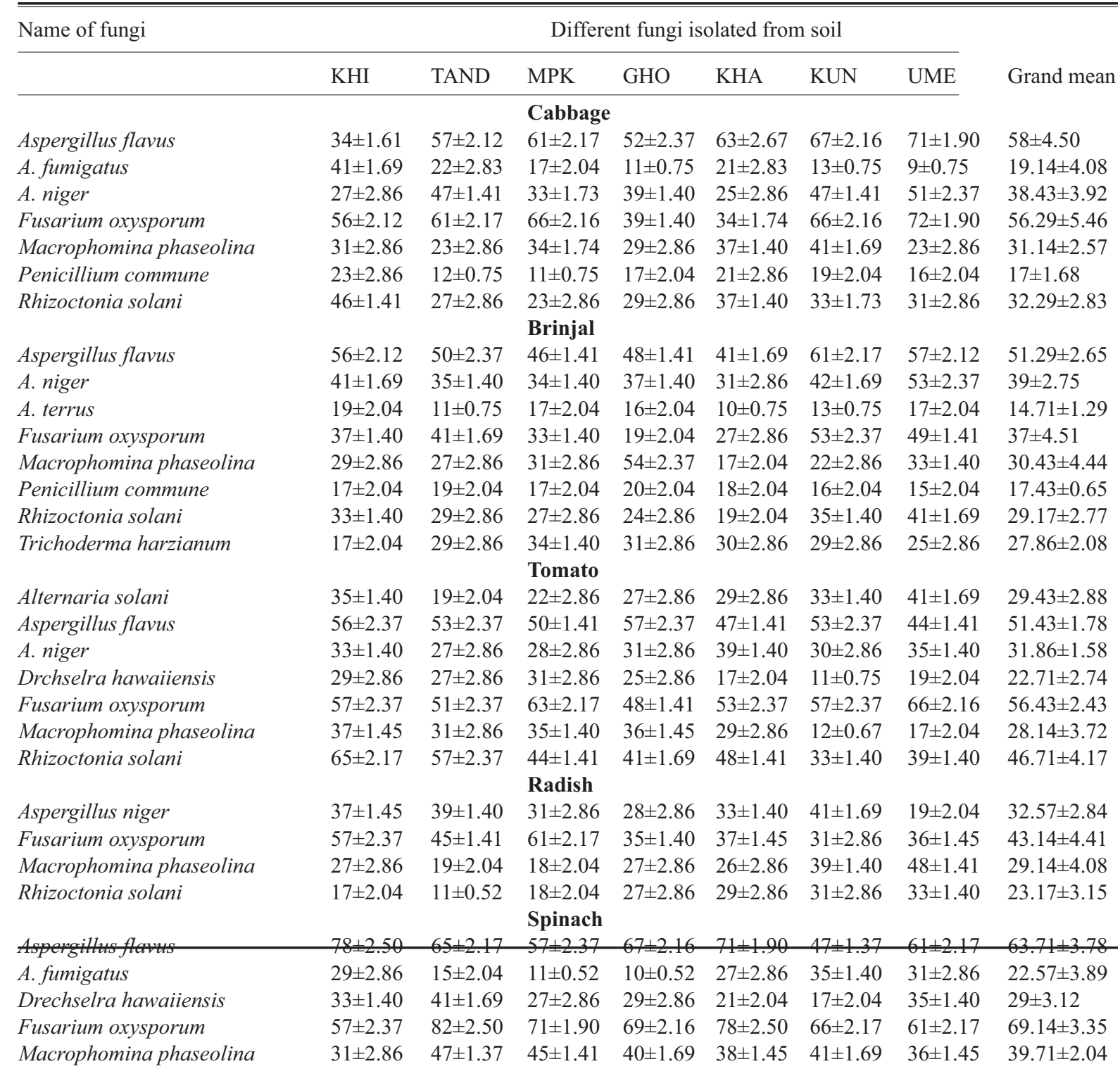

$\mathrm{KHI}=$ Karachi, $\mathrm{TAND}=$ Tando Allahyar, $\mathrm{MPK}=$ Mirpurkhas, $\mathrm{GHO}=$ Ghotaki, $\mathrm{KHA}=$ Khairpur, KUN $=\mathrm{Kunri}$, UME $=$ Umerkot.

average mean value of 56 and $32 \%$, respectively, as compared to other speciese i.e. Alternaria solani, Aspergillus flavus, A. fumigatus, A. niger, Rhizoctonia solani and Drechselra hawaiiensis. On the basis of regions' comparison, the occurrence of these fungi was maximum in the samples Tando Allahyar (82\%), Khairpur (78\%) and Mirpurkhas (71\%), respectively, and minimum (10\%) from Ghotaki region (Table 4).

Table 5 shows the results of ANOVA for the fungal infection $\%$ on soil samples collected from various localities of Sindh. Eleven fungal species including
Alternaria solani, Aspergillus flavus, A. fumigatus, A. niger, A. terrus, Drechselra hawaiiensis, Fusarium oxysporum, Macrophomina phaseolina, Penicillium commune, Rhizoctonia solani and Trichoderma harzianum showed high significant differences among localities. Nine species are pathogenic on all vegetables particularly cabbage, brinjal, tomato, radish and spinach crops. In brinjal Penicillium commune showed nonsignificant difference than other vegetables.

Meteorological conditions such as high temperature and low humidity during the summer contribute to fewer fungi 
Table 5. F-ratios derived from ANOVA for fungal infection $\%$ of soil

\begin{tabular}{|c|c|c|c|}
\hline Fungi species & F-ratio & P-value & $\mathrm{LSD}_{0.05}$ \\
\hline & \multicolumn{3}{|c|}{ Cabbage } \\
\hline Aspergillus flavus & 31.87 & $0.0000 * * *$ & 6.11 \\
\hline A. fumigatus & 33.08 & $0.0000 * * *$ & 5.30 \\
\hline A. niger & 24.40 & $0.0000 * * *$ & 5.93 \\
\hline Fusarium oxysporum & 53.89 & $0.0000 * * *$ & 5.56 \\
\hline Macrophomina phaseolina & 7.97 & $0.0000 * * *$ & 6.97 \\
\hline Penicillium commune & 4.59 & $0.0006^{* * *}$ & 5.84 \\
\hline \multirow[t]{2}{*}{ Rhizoctonia solani } & 9.94 & $0.0000 * * *$ & 6.71 \\
\hline & \multicolumn{3}{|l|}{ Brinjal } \\
\hline Aspergillus flavus & 13.16 & $0.0000 * * *$ & 5.46 \\
\hline A. niger & 14.63 & $0.0000 * * *$ & 5.37 \\
\hline A. terrus & 4.40 & $0.0009 * * *$ & 4.57 \\
\hline Fusarium oxysporum & 37.38 & $0.0000^{* * *}$ & 5.52 \\
\hline Macrophomina phaseolina & 21.77 & $0.0000 * * *$ & 7.11 \\
\hline Penicillium commune & 0.70 & $0.6453 \mathrm{~ns}$ & 5.77 \\
\hline Rhizoctonia solani & 10.58 & $0.0000^{* * *}$ & 6.35 \\
\hline \multirow[t]{2}{*}{ Trichoderma harzianum } & 4.49 & $0.0007 * * *$ & 7.31 \\
\hline & \multicolumn{3}{|l|}{ Tomato } \\
\hline Alternaria solani & 11.45 & $0.0000 * * *$ & 6.35 \\
\hline Aspergillus flavus & 5.49 & $0.0001 * * *$ & 5.69 \\
\hline A. niger & 3.17 & $0.0087 * *$ & 6.62 \\
\hline Drechselra hawaiiensis & 8.86 & $0.0000 * * *$ & 6.88 \\
\hline Fusarium oxysporum & 8.56 & $0.0000 * * *$ & 6.20 \\
\hline Macrophomina phaseolina & 24.99 & $0.0000^{* * *}$ & 5.56 \\
\hline \multirow[t]{2}{*}{ Rhizoctonia solani } & 40.39 & $0.0000^{* * *}$ & 4.90 \\
\hline & \multicolumn{3}{|l|}{ Radish } \\
\hline Aspergillus niger & 13.49 & $0.0000^{* * *}$ & 5.78 \\
\hline Fusarium oxysporum & 35.79 & $0.0000^{* * *}$ & 5.51 \\
\hline Macrophomina phaseolina & 22.16 & $0.0000^{* * *}$ & 6.47 \\
\hline \multirow[t]{2}{*}{ Rhizoctonia solani } & 13.89 & $0.0000^{* * *}$ & 6.32 \\
\hline & \multicolumn{3}{|c|}{ Spinach } \\
\hline Aspergillus flavus & 22.34 & $0.0000 * * *$ & 5.98 \\
\hline A. fumigatus & 23.82 & $0.0000 * * *$ & 5.96 \\
\hline Drechselra hawaiiensis & 15.13 & $0.0000^{* * *}$ & 5.98 \\
\hline Fusarium oxysporum & 15.35 & $0.0000 * * *$ & 6.38 \\
\hline Macrophomina phaseolina & 9.30 & $0.0000 * * *$ & 5.01 \\
\hline
\end{tabular}

while in the rainy season the concentration of fungi is significantly increased in the soil (Kakde et al., 2001). It is interesting to note that in Karachi, located in southern Sindh, studies on airborne mycobiota (Rao et al., 2009; Afzal et al., 2004) have demonstrated that the aerospora is dominated by Aspergillus flavus, A. niger and Alternaria solani. Thus, the atmospheric mycobiota trend to correspond with the soil of vegetable fungal dominance.
These results confirms the findings of Hussain et al. (2013a); Usman et al. (2013);Islam and Babadoost (2002) and Lee et al. (2001). The most frequent associated fungi isolated from the soil of vegetables are Alternaria solani, Aspergillus flavus, A. fumigatus, A. niger, A. oryzae, A. terrus, Aeromonium fusidiocles, Cladosporium sp., Drechselra hawaiiensis, Eurotium berbanbrum, Fusarium oxysporum, Macrophomina phaseolina, Penicillium commune, Rhizoctonia solani, Trichoderma harzianum, and Ulocladium sp., etc. These results prove that these fungi were most prevalent in the soil of fields and also found to be responsible for most of the decline of the vegetable crops.

This preliminary study provides basis for the determination of fungi from root and soil losses of vegetables which are most demanded in Pakistan. A detailed and investigative survey is required to establish the soil and root resistance strategies to reduce the losses both in terms of economic and food supply especially caused by fungi.

\section{References}

Afzal, M., Mehdi, F.S., Siddiqui, Z.S. 2004. Effect of relative humidity and temperature on airborne fungal allergens of Karachi city. Pakistan Journal of Biological Sciences, 7: 159-162.

Ali, M. 2000. Dynamics of Vegetable Production, Distribution and Consumption in Asia, Asian Vegetable Research and Development Center (AVRDC), Tainan, Taiwan.

Athar, M., Bokhari, T.Z. 2006. Ethnobotany and production constraints of traditional and commonly used vegetables of Pakistan. Journal of Vegetable Science, 12: 27-38.

Barnett, H., Hunter, B.B. 1972. Illustrated Genera of Imperfect Fungi, 241 pp., $3^{\text {rd }}$ edition, Burgess Publishing Co., Minneapolis, Minnesota, USA.

Domsch, K.H., Gams, W., Anderson, T.H. 1980. Compendium of Soil Fungi, vol. I, 860 pp., Academic Press, London, UK.

Ellis, E.B. 1976. More Dematiaceous Hyphomycetes, 507 pp., Commonwealth Mycological Institute, Kew, UK.

Ellis, M.B. 1971. Dematiaceous Hyphomycetes, 608 pp., Surrey, Kew, CMI., UK.

Fatima, N., Batool, H., Sultana, V., Ara, J., EhteshamulHaque, S. 2009. Prevalence of post-harvest rot of vegetables and fruits in Karachi, Pakistan. Pakistan Journal of Botany, 41: 3185-3190. 
Hanif, R., Iqbal, Z., Iqbal, M., Hanif, S., Rasheed, M. 2006. Use of vegetables as nutritional food: Role in human health. Journal of Agricultural and Biological Science, 1: 18-22.

Hussain, F., Shaukat, S.S., Abid, M., Usman, F., Akbar, M. 2013a. Pathogenicity of some important rootrot fungi to the chilli crop and their biological control. International Journal of Biology and Biotechnology, 10: 101-108.

Hussain, F., Shaukat, S.S., Abid, M., Usman, F., Akbar, M. 2013b. Filamentous fungi infecting fruits and leaves of Capsicum annuum L. in lower Sindh. International Journal of Biology and Biotechnology, 10: 109-116.

Hussain, F., Shaukat, S.S., Abid, M., Usman, F., Akbar, M. 2013c. Control of Meloidogyne javanica and Fusarium solani in chilli (Capsicum annuum L.) with the application of chitin. Pakistan Journal of Nematology, 31: 165-170.

Hussain, F., Shaukat, S.S., Abid, M., Usman, F. 2012. Some important medicinal plants associated with the vegetation in District Mirpurkhas, Sindh. International Journal of Biology and Biotechnology, 9: 405-420.

Hussain, F., Abid, M. 2011. Pests and diseases of chilli crop in Pakistan: A review. International Journal of Biology and Biotechnology, 8: 325-332.

Islam, S.Z., Babadoost, M. 2002. Effect of red light treatment of seedlings of pepper, pumpkin and tomato on occurrence of Phytophthora dampingoff. HortScience, 37: 678-681.

Kakde, U.B., Hemalata, U.K., Aarti, A.S. 2001. Seasonal variation of fungal propagules in a fruit market environment, Nagpur (India). Aerobiologia, 17: 177-182.

Khalil, I.A., Rehman, S. 1977. Ber (Zizyphus jujuba Mill.) as a nutritive fruit. Journal of Science and Technology, (Univ. Peshawar). 1: 126-128.

Lee, B.K., Kim, B.S., Chang, S.W., Hwang, B.K. 2001. Aggressiveness to pumpkin cultivars of isolates of Phytophthora capsici from pumpkin and pepper. Plant Disease, 85: 497-500.

Maqbool, M.A., Hashmi, S., Ghaffar, A. 1988. Problem of root-knot nematodes in Pakistan and strategy for their control. In: Advances in Plant Nematology. Proceeding of United States-Pakistan International Workshop on Plant Nematology, M.A. Maqbool et al. (eds.), pp. 229-240, NNRC, University of Karachi, Pakistan.

Mirza, J.H., Qureshi, M.S.A. 1978. Fungi of Pakistan, 311 pp., University of Agriculture, Faisalabad, Pakistan.

Nelson, P.E., Toussoun, T.A., Marasas, W.F.O. 1983. Fusarium Species: An Illustrated Manual for Identification, 206 pp., The Pennsylvania State University Press, University Park, PA., USA.

Promputtha, I., Jeewon, R., Lumyong, S., McKenzie, E.H.C., Hyde, K.D. 2005. Ribosomal DNA fingerprinting in the identification of non sporulating endophytes from Magnolia liliifera (Magnoliaceae). Fungal Diversity, 20: 167-186.

Rao, T.A., Sheikh A.H., Ahmed, M.. 2009. Airborne fungal flora of Karachi. Pakistan Journal of Botany, 41: 1421-1428.

Sheikh, A.H., Ghaffar, A. 1992. Effect of fungicide on the survival of sclerotia of Macrophomina phaseolina at different soil manure levels and its infection on guar (Cyamopsis tetragonoloba). Proceeding of National Symposium on Status of Plant Pathology in Pakistan, (3-5 Dec. 1991), A. Ghaffar, and S. Shahzad (eds.), pp. 267-271, Department of Botany, University of Karachi, Karachi. 75270, Pakistan.

Sinclair, J.B. 1982. Compendium of Soybean Diseases, 104 pp., $2^{\text {nd }}$ edition, American Phytopathological Society and University of Illinois, IL, USA.

Singh, K., Frisvad, J.C., Thrane, U., Mathur, S.B. 1991. An Illustrated Manual on Identification of Some Seed-Borne Aspergilli, Fusaria, Penicillia and Their Mycotoxins, 133 pp., $1^{\text {st }}$ edition, Danish Government Institute of Seed Pathology for Development Countries, Denmark.

Sutton, B.C. 1980. The Coelomycetes. Fungi Imperfecti with Pycnidia, Acervuli and Stromata, 696 pp., Commonwealth Mycological Institute, Kew, Surrey, UK.

Usman, F., Shaukat, S.S., Abid, M., Hussain, F. 2013. Rhizosphere fungi of different vegetables and their antagonistic activity against pathogenic fungi of brinjal and spinach. International Journal of Biology and Biotechnology, 10: 255-259.

Waksman, S.A., Fred, E.B., 1922. A tentative outline of the plate method for determining the number microorganisms in the soil. Soil Science, 14: 27-28. 